\title{
LONG-TERM STABILITY \\ OF Co-C AND Pd-C EUTECTIC FIXED POINTS \\ FOR THERMOCOUPLES CALIBRATION
}

\author{
Yasser A. Abdelaziz, Ph.D., Prof., e-mail: yasserabdelfatah@yahoo.com; \\ F. M. Megahed, Ph.D., Prof.; M. M. Abdel-Aal, Ph.D. \\ National Institute for Standards, Egypt
}

\begin{abstract}
Eutectic fixed points are close to becoming a reference for high temperatures calibration, especially as the new International Temperature Scale (ITS) approach to issue after the re-definition of the Kelvin unit.

In this work, the long-term stability of Co-C and Pd-C eutectic fixed points were investigated using NIS-Egypt facilities. The eutectic points were measured using $\mathrm{Pt} / \mathrm{Pd}$ thermocouple. The total exposure to the $\mathrm{Co}-\mathrm{C}$ and $\mathrm{Pd}-\mathrm{C}$ melting temperature was about $200 \mathrm{~h}$ for the fixed-point cell and $150 \mathrm{~h}$ for the $\mathrm{Pt} / \mathrm{Pd}$ thermocouple. The EMFs of the thermocouple at the melting point was observed to drift by about $0.25^{\circ} \mathrm{C}$.

Realization uncertainties were estimated to be $\sim 0.446{ }^{\circ} \mathrm{C}$ for $\mathrm{Co}-\mathrm{C}$ and $\sim 0.742$ for $\mathrm{Pd}-\mathrm{C}(\mathrm{k}=2)$. Results show that $\mathrm{Co}-\mathrm{C}$ and Pd-C eutectic cells can exhibit long-term stability.

Key words: Eutectic Fixed Points, Stability, Thermocouples, Uncertainty.
\end{abstract}

\section{Introduction}

For contact thermometry, Metal-carbon (M-C) eutectic fixed points represent an important development in the uncertainty of thermocouple calibration at high temperatures.

A lot of research has been carried out to verify the possibility of using eutectic points as new fixed points, some of those studies evaluated their long-term stability [1, $2 \& 3]$. It is important to study all other known eutectic points for longer periods, to choose the most suitable in the future as a fixed point.

Noble metal thermocouples can be used to measure temperatures up to $1600{ }^{\circ} \mathrm{C}$ without serious difficulties.

\section{The Aim of the Research}

In the present work, we use reference noble metal thermocouple $\mathrm{Pt} / \mathrm{Pd}$ to investigate the long-term stability of the eutectic points of $\mathrm{Co}-\mathrm{C}$ and $\mathrm{Pd}-\mathrm{C}$.

\section{Measurement set-up}

\subsection{Eutectic Fixed Points}

The Co-C and Pd-C cells were supplied and calibrated by NPL-UK, see cells information in Table 1 . The cell design is illustrated in Fig. 1 [4]. Crucibles were made from pure graphite and they should be properly purified again after manufacturing by heating in an inert atmosphere or preferably vacuum before filling. Each cell is filled with a mixture of powder of high-purity metal and high-purity carbon. Assembled crucibles were mounted in a graphite equalizing block, in a three-zone furnace.

Table 1

\section{Fixed points data}

\begin{tabular}{|l|c|c|}
\hline Parameter & Co-C & Pd-C \\
\hline Supplier & NPL & NPL \\
\hline Metal Purity & 99.995 & 99.995 \\
\hline Graphite powder purity & 99.9999 & 99.9999 \\
\hline
\end{tabular}

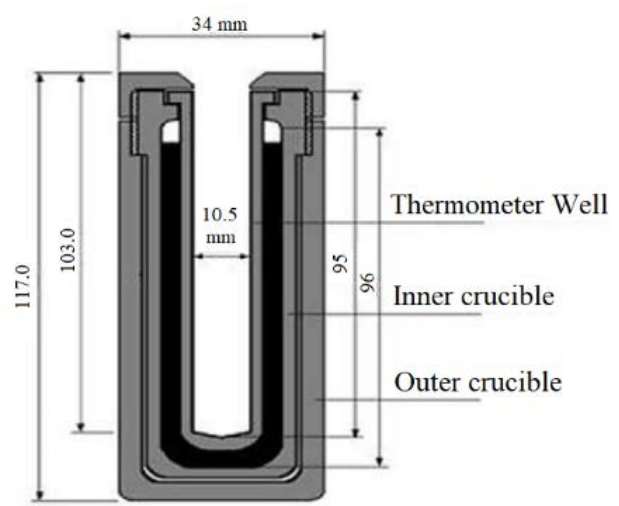

Figure 1. Design of the eutectic fixed-point cell.

\subsection{Eutectic Point Furnace}

A high-temperature three-zone furnace (Elite TMV16/75/610) was used in this work. Each heater of the furnace has a controller used to set the required temperature by adjusting the desired set-point and the ramp rate. The furnace is warmed to about $1316{ }^{\circ} \mathrm{C}$ for $\mathrm{Co}-\mathrm{C}$ cell or $1484{ }^{\circ} \mathrm{C}$ for $\mathrm{Pd}-\mathrm{C}$ cell. The approximate temperature is monitored using the furnace center zone indicator.

In this work, the temperature profile (evaluation of furnace axial homogeneity or thermal gradient) was 
checked each $2 \mathrm{~cm}$ after furnace stabilizing over-night or until the test probe reaches stability of $<0.1^{\circ} \mathrm{C}$ for greater than 15 minutes. The profile of the eutectic point furnace was carried out at $1270{ }^{\circ} \mathrm{C}$ according to the manufacturer (NPL-UK) recommendations. The furnace profile shows stability $\pm 0.39{ }^{\circ} \mathrm{C}$ at $1270{ }^{\circ} \mathrm{C}$ for $10 \mathrm{~cm}$ immersion (eutectic furnaces are usually used with small cells). So, the above-mentioned temperature regions are convenient to locate the fixed-point cells in these regions (low gradient and uniform regions) within the furnaces.

\subsection{Pt/Pd Thermocouples}

$\mathrm{Pt} / \mathrm{Pd}$ thermocouple was prepared and assembled at NIS-Egypt according to the international standards and recommendations [5], using $0.5 \mathrm{~mm}$ diameter wires with $200 \mathrm{~cm}$ length. All wires were supplied by Johnson Matthey as high reference-grade, (with the purity of $99.999 \%$ for platinum wire and $99.997 \%$ purity palladium wire).

The thermocouple reference junction was maintained at $0{ }^{\circ} \mathrm{C}$ in a Dewar flask filled with a mixture of distilled water and crushed ice (ice bath). The reference junction was inserted for $20 \mathrm{~cm}$ in the ice bath using a closed-end glass tube.

\subsection{Nano Voltmeter}

The digital Nanovoltmeter Keithly voltmeter type182) used in this work has internal resistance higher than $10^{9} \Omega$ was used to measure emf, its resolution corresponds to temperature resolution of $1 \mathrm{~m}^{\circ} \mathrm{C}$ and $48 \mathrm{nV}$ accuracy.

\section{Measurement Results and Discussion}

\subsection{Measuring of Eutectic Fixed Points} in Different Time Stages

Each Co-C and Pd-C cells were exposed for about $200 \mathrm{~h}$ and over $40 \mathrm{melting} /$ freezing cycles in 2014, 2016, and 2018. Final tests were performed in June 2019.

The measuring of eutectic points up to $1500{ }^{\circ} \mathrm{C}$ is carried out by inserting the thermocouple into a substantial ingot of Co-C and Pd-C.
The eutectic fixed point was inserted in a graphite shield (without touching the sides shield) in the most uniform region of a three-zone furnace. The cell assembly is mounted in a re-crystallized alumina tube, this assembly is completely sealed to permit a flowing argon gas atmosphere under controlled pressure. The emf output of the thermocouples used in these measurements is recorded at least every 10 seconds using a logging program.

\subsection{Observed plateaus}

The shapes of observed melting and freezing plateaus can use to estimate the long-term stability of the cells. Five sets of melt/freeze were realized and recorded for each cell over about 6 years. All melting plateaus are compared and plotted as shown in Fig. 2-3. There is a slight change in plateau duration and plateau shape, some of these changes may be related to the drift of the $\mathrm{Pt} / \mathrm{Pd}$ thermocouple. Whereas, many previous studies have shown regression of $\mathrm{Pt} / \mathrm{Pd}$ thermocouple when studying its long-term stability. As F. Edler and et al tested the thermoelectric stability of the $\mathrm{Pt} / \mathrm{Pd}$ thermocouples exposed to temperatures up to about $1350{ }^{\circ} \mathrm{C}$ for 250 hours, they found the $\mathrm{Pt} / \mathrm{Pd}$ thermocouples stability is about $100 \mathrm{~m}{ }^{\circ} \mathrm{C}$, measured at the freezing point of silver [6].

For, $\mathrm{Co}-\mathrm{C}$, the scatter of the melting temperature is within $\pm 4 \mu \mathrm{V}\left( \pm 170.5 \mathrm{~m}^{\circ} \mathrm{C}\right)$. For Pd-C, the scatter of the melting temperature is within $\pm 2 \mu \mathrm{V}\left( \pm 79.1 \mathrm{~m}^{\circ} \mathrm{C}\right)$, using calibrated $\mathrm{Pt} / \mathrm{Pd}$ thermocouple, with no visible trend, which reflects the good stability for both cells and $\mathrm{Pt} / \mathrm{Pd}$ thermocouple. The melting plateaus durations are about 150 sec. for $\mathrm{Co}-\mathrm{C}$ and $90 \mathrm{sec}$. for Pd-C eutectic cell.

Table 2 and Fig. 4 shown an observed unexpected decrease in thermoelectric emf resulting from Co-C cell in Aug. 2015, this is mainly due to the drift of $\mathrm{Pt} / \mathrm{Pd}$ thermocouple, this can be explained also from and Fig. 4, Pd-C cell, where the measurement carried out in same test days with same thermocouple, very similar change trend is observed. Here, each plot represents a plateau.

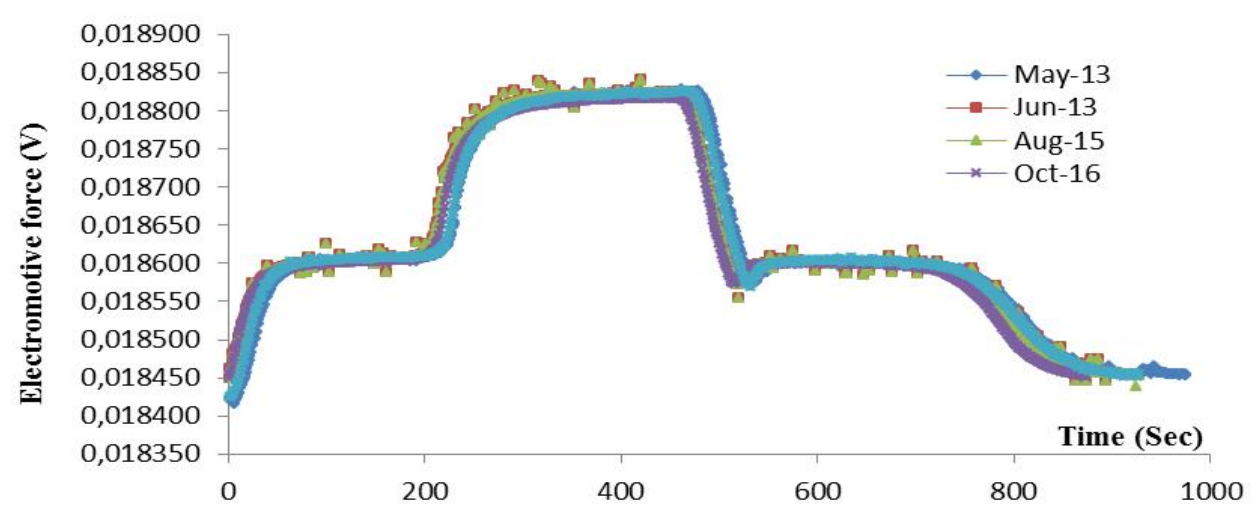

Figure 2. Melting and freezing curve of in Co-C eutectic fixed point, measured by Pt/Pd thermocouple 


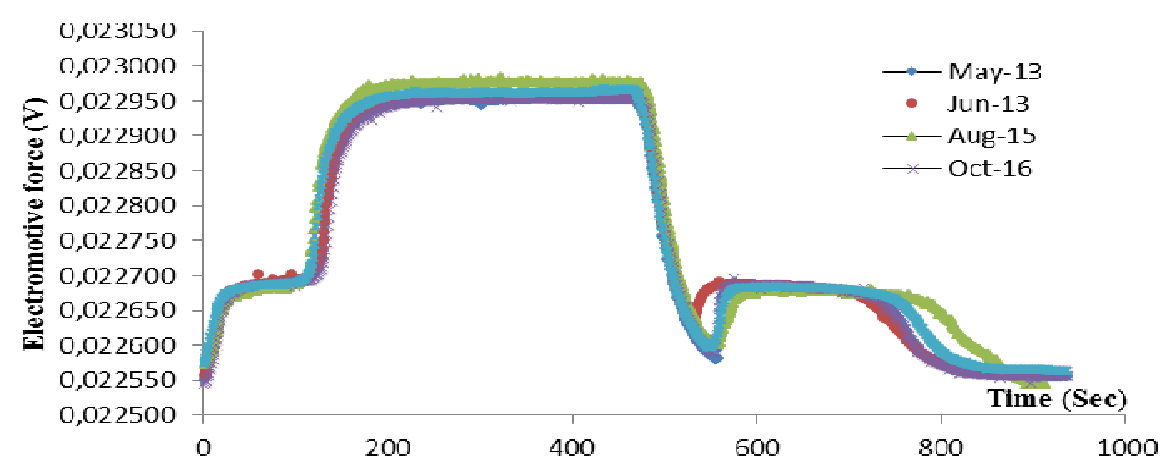

Figure 3. Melting and freezing curve of in Pd-C eutectic fixed point, measured by Pt/Pd thermocouple

Table 2

Stability results of Co-C and Pd-C eutectic fixed

\begin{tabular}{|c|c|c|}
\hline \multirow{2}{*}{ Date } & Co-C & Pd-C \\
\cline { 2 - 3 } & $\mu \mathrm{V}$ & $\mu \mathrm{V}$ \\
\hline May 2013 & 18603.54 & 22688.03 \\
\hline June 2013 & 18606.00 & 22688.79 \\
\hline Aug. 2015 & 18604.00 & 22687.30 \\
\hline Oct. 2016 & 18605.32 & 22689.74 \\
\hline June 2019 & 18607.00 & 22688.37 \\
\hline
\end{tabular}
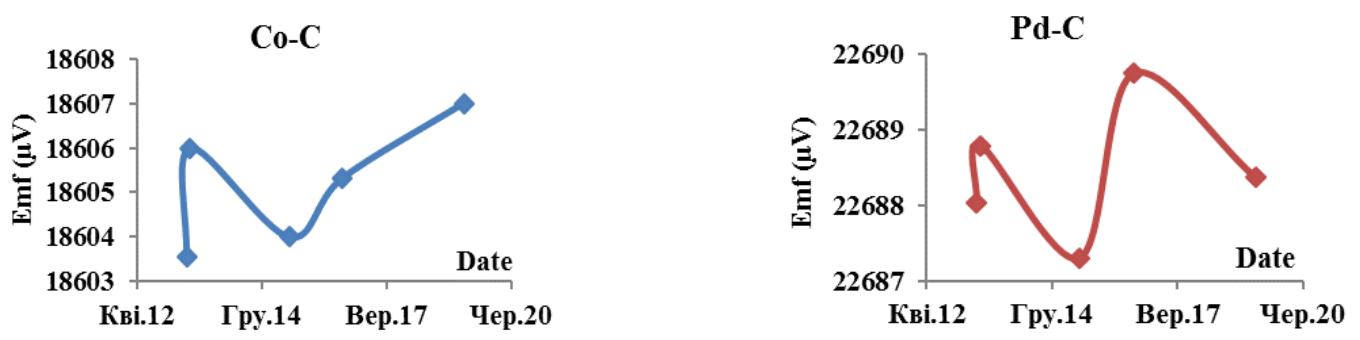

Fig. 4. Melting temperature Co-C and Pd-C cells during the test

Table 3

$\mathrm{Pt} / \mathrm{Pd}$ thermocouple repeatability in $\mathrm{Cu}$ freezing point.

\begin{tabular}{|c|c|c|c|c|c|c|c|}
\hline \multicolumn{5}{|c|}{$\begin{array}{c}\text { Measurement run at } \mathrm{Cu} \text { freezing point } 1084.62^{\circ} \mathrm{C} \text {, } \\
\mathrm{uV}\end{array}$} & \multirow[t]{2}{*}{$\begin{array}{l}\mathrm{dE} / \mathrm{dt} \\
\mu \mathrm{V} /{ }^{\circ} \mathrm{C}\end{array}$} & \multicolumn{2}{|c|}{ Repeatability } \\
\hline $1^{\mathrm{st}}$ & $2^{\text {nd }}$ & $3^{\text {rd }}$ & $4^{\text {th }}$ & $5^{\text {th }}$ & & $\mu \mathrm{V}$ & ${ }^{\circ} \mathrm{C}$ \\
\hline 13276.0 & 13275.4 & 13275.2 & 13275.8 & 13275.6 & 20.9 & 0.32 & 0.02 \\
\hline
\end{tabular}

4.3. Repeatability of the thermocouple at $\mathrm{Cu}$ freezing point

$\mathrm{Pt} / \mathrm{Pd}$ thermocouples are subject to drift with use, especially at high temperatures. Where, platinum is sensitive to the presence of impurities, with which it can combine to form a eutectic alloy. High-purity protecting tubes during routine use are essential to help prevent this [7]. So, it was necessary to confirm the repeatability of $\mathrm{Pt} / \mathrm{Pd}$ thermocouple using one of the ITS-90 fixed points, as a standard used for evaluating eutectic cell stability.

Table 3 shows the $\mathrm{Pt} / \mathrm{Pd}$ thermocouple repeatability in emf values in the $\mathrm{Cu}$ freezing point. The overall repeatability is $\pm 0.32 \mu \mathrm{V}\left( \pm 20 \mathrm{~m}^{\circ} \mathrm{C}\right)$.

\subsection{Thermoelectric Homogeneity}

The uncertainty arising from the thermoelectric inhomogeneity has a relatively large contribution to the thermocouple uncertainty at fixed points, and it is important to characterize this contribution as accurately as possible [7], the insertion/withdrawal technique was carried out at the Ag freezing point as described by McLaren and et. al. [8].

In this technique, the thermocouple was inserted slowly into the cell after initiating the freeze and its measuring junction was positioned $2 \mathrm{~cm}$ below the surface of the metal. The thermocouple was held at this location for $15 \mathrm{~min}$ and then its emf was measured. The 
immersion of the thermocouple was then increased by 2 $\mathrm{cm}$ and after $5 \mathrm{~min}$ its emf was again measured.

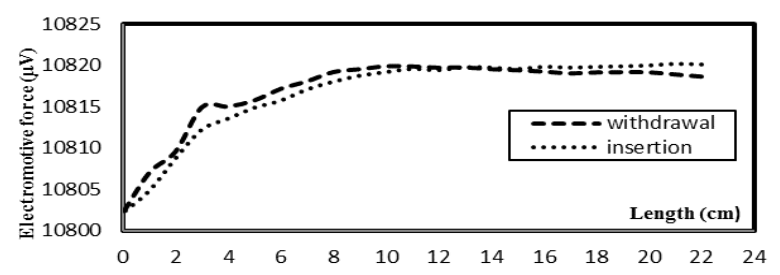

\section{Figure 5. Thermoelectric homogeneity test of Pt/Pd thermocouple}

This procedure was repeated until the thermocouple was fully immersed in the freezing point cell. After it was held at full immersion for about $15 \mathrm{~min}$, its emf was measured. It was then withdrawn from the cell at the rate of $2 \mathrm{~cm}$ per min and its emf was measured while its measuring junction was held at each of the immersion locations used during insertion. The obtained results are presented in Figure 5.
The profile indicates inhomogeneity equivalent in temperature to $\sim 41.7 \mathrm{~m}^{\circ} \mathrm{C}$. This may be due to the reason that the stress-relieving coil has the measurable effect that decreased with the fixed-point temperature increase [7]. These results demonstrate that about $11 \mathrm{~cm}$ of immersion is required in the fixed-point cell to overcome thermal conduction effects.

\subsection{Uncertainty of measurements}

Uncertainties of measurement calculated following EA guide 'Expression of the Uncertainty of Measurement in Calibration EA-4/02' [8]. The uncertainty budget of the thermocouple at eutectic fixed points incorporating the various contributory factors is shown in Table 4.

Uncertainties for the items labeled repeatability are typically evaluated as Type A uncertainties, using statistical methods. The other items are primarily evaluated using Type B methods. The combined uncertainty $U_{C}$ is expressed in the form of a $95 \%$ confidence level $(\mathrm{k}=2)$. All uncertainty sources are described in the previous sections.

Table 4

Uncertainty budget of thermocouple type $\mathrm{Pt} / \mathrm{Pd}$ in eutectic fixed points

\begin{tabular}{|c|c|c|}
\hline \multirow{2}{*}{ Expected components of uncertainty } & \multicolumn{2}{|c|}{ Fixed point ingots, $\mu \mathrm{V}$} \\
\hline & Co C & Pd C \\
\hline Statistical standard uncertainty & 0.64 & 0.41 \\
\hline Determination of the fixed-point temperature & 5.192 & 9.361 \\
\hline Voltmeter calibration & 0.38 & 0.38 \\
\hline Voltmeter resolution & $5.77 \mathrm{E}-06$ & $5.77 \mathrm{E}-06$ \\
\hline Voltmeter drift & 0.0577 & 0.0577 \\
\hline Thermocouple homogeneity @ Ag freezing point, see section 3.4 & 0.4619 & 0.4619 \\
\hline Reference junction & 0.1529 & 0.1529 \\
\hline Combined standard uncertainty $\mathrm{U}_{\mathrm{C}}, \mu \mathrm{V}$ & 5.268 & 9.390 \\
\hline Corresponding Combined uncertainty $\mathrm{U}_{\mathrm{C}},{ }^{\circ} \mathrm{C}$ & 0.223 & 0.371 \\
\hline Expanded uncertainty $\mathrm{U} @(\mathrm{k}=2),{ }^{\circ} \mathrm{C}$ & 0.446 & 0.742 \\
\hline
\end{tabular}

\section{Conclusion}

There are not many publications on the long-term stability of Eutectic fixed points, especially studies over several working years. This is due to the difficulties of measurement at the high temperatures involved. In this work the $\mathrm{Co}-\mathrm{C}$ and $\mathrm{Pd}-\mathrm{C}$ cells have been investigated for long-term stability (along 6 years), a slight increase appeared in melting values after about $200 \mathrm{~h}$ and over 40 melting/freezing cycles.

The temperature drifts observed for the Co-C cell is within $\pm 4 \mu \mathrm{V}\left( \pm 170.5 \mathrm{~m}^{\circ} \mathrm{C}\right)$, but for Pd-C, is within \pm $2 \mu \mathrm{V}\left( \pm 79.1 \mathrm{~m}^{\circ} \mathrm{C}\right)$, using calibrated $\mathrm{Pt} / \mathrm{Pd}$ thermocouple.

The uncertainty of the realization of $\mathrm{Co}-\mathrm{C}$ and $\mathrm{Pd}-$ $\mathrm{C}$ eutectic fixed points was estimated to be approximately $0.446{ }^{\circ} \mathrm{C}$ for $\mathrm{Co}-\mathrm{C}$ and 0.742 for Pd-C $(@ \mathrm{k}=2)$.

\section{References}

[1] Y. Yamada, Y. Wang, "Long-Term Stability of Metal-Carbon Eutectic Fixed-Point Cells", Acta Metrologica Sinica, 2008.
[2] M. Sadli, P. Bloembergen, B. Khlevnoy, T. Wang, Y. Yamada, G. Machin, "An International Study of the Long-Term Stability of Metal-Carbon Eutectic Cells", International Journal of Thermophysics, vol. 32, pp. 1786-1799, 2011.

[3] T. Wang, C. Bai, W. Dong, Z. Yuan, P. Bloembergen, F. Liu, "Results of Long-Term Stability Tests Performed for the Eutectics $\mathrm{Co}-\mathrm{C}$ and $\mathrm{Pt}-\mathrm{C}$ ", International Journal of Thermophysics, vol. 32, pp. 1719-1731, 2011.

[4] Yasser A. Abdelaziz1, H. M. Hashem, M. M. AbdelAal, F. M. Megahed, M. Hammam, "Development of High Temperature Thermocouples Calibration at NIS-Egypt", Journal of Scientific and Engineering Research, vol. 5, 2018.

[5] E. Bentley, "Thermoelectric instability in Pd within the elemental thermocouple $\mathrm{Pt} / \mathrm{Pd}$ ", Measurement Science and Technology, vol. 12, p.1250, 2001.

[6] H. Numajiri, H. Ogura, M. Izuchi, M. Arai, "Emf Changes of the Pt/Pd Thermocouples at the Freezing Point of Silver", SICE 2003 Annual Conference, 2003.

[7] E. McLaren, E. Murdock, "Au/Pt thermocouple", Ottawa, National Research Council of Can, NRCC/27703, 1987.

[8] EA, Expression of the Uncertainty of Measurement in Calibration. publ. by EA-4/02, 2013. 